\title{
Contribution to canine babesiosis in the Czech Republic
}

\author{
Jarmila Konvalinová1, Ivo Rudolf ${ }^{2}$, Silvie Šikutová ${ }^{2}$ Zdeněk Hubálek ${ }^{2}$, \\ Vlasta Svobodová ${ }^{3}$, Miroslav Svoboda ${ }^{1}$ \\ ${ }^{1}$ Clinic of Dog and Cat Diseases, Faculty of Veterinary Medicine, University of Veterinary and Pharmaceutical \\ Sciences Brno, Czech Republic \\ ${ }^{2}$ Institute of Vertebrate Biology, v.v.i., Academy of Sciences of the Czech Republic, Medical Zoology \\ Laboratory, Valtice, Czech Republic \\ ${ }^{3}$ Department of Parasitology, Faculty of Veterinary Medicine, University of Veterinary and Pharmaceutical \\ Sciences Brno, Czech Republic \\ Received December 14, 2011 \\ Accepted April 11, 2012
}

\begin{abstract}
From March to November 2010, a total of 68 samples of blood from 41 hunting and working dogs that never left the Czech Republic were examined. Some dogs were sampled repeatedly. Blood samples were examined by polymerase chain reaction for the presence of DNA of piroplasms with negative results. Specific IgG antibodies against Babesia canis were detected by indirect immunofluorescence test, and five dogs $(12.21 \%)$ were seropositive. Titres ranged from 50 to 200. One dog was positive in two samplings within 3 months. The highest number of positive samples was taken in June. The results of this study suggest a likely contact of the examined dogs with the parasite; although in 2005, a total of 340 adult unfed Dermacentor reticulatus ticks in 34 pools screened by PCR for babesiae were negative.
\end{abstract}

Dogs, Babesia canis, antibodies, Dermacentor reticulatus

Canine babesiosis, one of the most important emerging tick-borne diseases of dogs with worldwide distribution, is transmitted by intra-erythrocytic protozoan of the genus Babesia. Traditionally, identification of species is based on morphology and host specificity. According to these criteria, canine piroplasms are divided into two distinct species, the large $(4-5 \mu \mathrm{m})$ Babesia canis and the small $(2.5 \mu \mathrm{m})$ Babesia gibsoni. Based on the differences in geographical distribution, vector specificity, antigenic properties, pathogenicity and ss-ribosomal RNA gene three subspecies of $B$. canis are distinguished, namely $B$. canis canis transmitted by Dermacentor reticulatus in Europe, B. canis vogeli transmitted by Rhipicephalus sanguineus in tropical and subtropical regions, and highly pathogenic B. canis rossi transmissible by Haemaphysalis leachi in South Africa (Uilenberg 2006). B. canis canis is the most importcant agent of babesiosis in Europe.

The incidence of Dermacentor reticulatus in the Czech Republic is limited to the basins of the Morava and Dyje rivers in the Břeclav and Hodonín regions and along the border with Slovakia (Kubelová and Široký 2010) (Fig. 1). The activity of adults has two peaks, with the first being in the spring from early March (however, ticks can be observed as early as late February, depending on weather conditions - adults are sometimes found even on snow) to mid April. The second peak of adults' activity starts in September. This tick species inhabits mainly lowland biotopes, waterlogged broadleaved forests, meadows, inundated areas of rivers and fringes of forests. Incidence of Dermacentor reticulatus is irregular and insular. In Central Europe, autochthonous canine babesiosis due to B. canis was recorded in several countries. Surprisingly, no autochthonous case of canine babesiosis was reported so far in the Czech Republic, although babesiosis is present in all the countries surrounding the Czech Republic and the competent vector of the disease frequently occurs (Svobodová and Svobodová 2004). In Slovakia, first cases of autochthonous babesiosis

Address for correspondence:

Jarmila Konvalinová

Clinic of Dog and Cat Diseases, Faculty of Veterinary Medicine

University of Veterinary and Pharmaceutical Sciences Brno

Palackého tř. 1/3, 61242 Brno, Czech Republic
Phone: +420541562375

E-mail: konvalinovaj@vfu.cz

http://actavet.vfu.cz/ 
started to emerge in 1997; the first case of babesiosis in dog was documented in 2000 (Chandoga et al. 2002). The incidence of babesiosis nearest to the Czech Republic was observed in the neighborhood of Malacky, Slovakia. So far, only imported babesiosis has been observed in the Czech Republic - the first imported infection was described in 1992 (Kučera 1992).

Dynamics of the spreading of canine babesiosis in Europe markedly changed in the last few years. This is largely connected with the expanding area of $D$. reticulatus distribution. In fact, the expansion of the vector's area and the increasing number of clinical cases of babesiosis has been observed also in all adjacent countries. Babesiosis has spread to Germany, Austria, Hungary and Poland as well as Switzerland (Földvári and Farkas 2005; Sréter et al. 2005; Duh et al. 2006; Zygner and Wedrychowicz 2006; Zygner et al. 2008; Hornok and Farkas 2009).

Babesiosis is a serious dog disease. Typical symptoms of acute babesiosis include apathy, anorexia, fever and general weakness. The disease leads to haemolytic anaemia along with thrombocytopaenia, lymphadenopathy and splenomegaly. Jaundice and haematuria can occur as well. Clinical signs are often very variable and the disease can have mild to peracute course that results in death within 2 days. Incubation period of B. canis is 10 to 21 days (Boozer and Macintire 2003). The infection induces an antibody reaction which is usually not strong enough to eliminate all babesiae in a host organism. Animals therefore become chronic carriers of the infection (Vercammen et al. 1997). In most cases, antibodies occur within 8 to 10 days after the infection. Puppies under 2 months of age can have colostral antibodies. Poor immune reaction is typical for puppies under 8 months of age. Antibody levels start to decrease 5 to 8 months after the animal went through the infection. Protection of dogs that underwent the disease against reinfection with the same Babesia species lasts 5 to 8 months on average. Antibodies acquired after the infection with one Babesia species do not protect against the infection with other species (Boozer and Macintire 2003; Uilenberg 2006). In certain studies, parasitaemia was detected in up to $36 \%$ of serologically negative dogs (Taboada 1998). Animals that recover from the infection and live in endemic localities acquire the so-called pre-immunity, i.e. nonsterile immunity. This means that the parasite survives in the host organism and eliminates reinfections. To the best of the authors' knowledge, no comprehensive study on $B$. canis canis and its main tick vector $D$. reticulatus nor systematic survey of dogs from endemic localities for the presence of antibodies to B. canis was conducted in the Czech Republic.

The aim of our study was to examine a group of dogs living in the region where emergence of $B$. canis infection might be expected. The presence of $D$. reticulatus vector was confirmed in that locality. Moreover, it is located near to Slovakia where the disease commonly occurs. Examinations of dogs followed up the pilot study which was carried out to assess prevalence of $B$. canis canis in D. reticulatus ticks in the South Moravia region (Czech Republic), where the vector is widespread and enzootic focus of tularaemia occurs (Hubálek et al. 1996).

\section{Materials and Methods}

From March to November 2010, a total of 41 dogs of 11 breeds (Siberian husky being the most frequent breed) were examined. The sample included 21 males (one of them castrated) and 19 females, aged 1 to 12 years. The body weight of these dogs ranged from 6 to $42 \mathrm{~kg}$. All animals came from the Břeclav district (Břeclav and Lanžhot localities) where $D$. reticulatus occurs. They were hunting and working dogs that never left this territory. As the dogs often worked in the field, they were more likely to be infested with ticks. All animals were clinically healthy. Blood samples of some of them were collected repeatedly. Of a total of 41 dogs, blood samples of 21 animals were collected once, 7 dogs were sampled twice and 13 animals thrice. A total of 68 blood samples were collected. Samples were taken at monthly intervals at the least. Blood was sampled in March, April, June and November.

Blood samples were taken from v. cephalica antebrachii. Samples of full blood (inserted in EDTA) and blood serum were obtained from each dog. Full blood samples were examined by PCR method. DNA was 
extracted from the samples using the commercial kit QIAGEN NucleoSpin Blood (Machery-Nagel, Germany) as prescribed by the manufacturer. To amplify the diagnostic fragment of the 91 piroplasmid SSU rRNA gene, we designed the forward primer TB-F (5'-CTTCAGCACCTTGAGAGAAAT-3') and the reverse primer TB-R (5'-TCDATCCCCRWCACGATGCRBAC-3'). Amplification condition were: 5 min at $94{ }^{\circ} \mathrm{C}, 39$ cycles each of $94{ }^{\circ} \mathrm{C}$ for $45 \mathrm{~s}, 62{ }^{\circ} \mathrm{C}$ for $30 \mathrm{~s}$, and $72{ }^{\circ} \mathrm{C}$ for $45 \mathrm{~s}$, with the addition of a final extension period of 10 min at $72{ }^{\circ} \mathrm{C}$. DNA isolated from the dog with confirmed imported $B$. canis infection (it was a patient at our clinic) was used as a positive control. Specific IgG antibodies against Babesia canis were detected by indirect immunofluorescence using the commercial Babesia canis IFA IgG Antibody Kit (Fuller Laboratories Fullerton, California, USA). The kit manufacturer states that titres 50 and more suggest recent or current infection. Hostseeking adult $D$. reticulatus were collected by flagging low vegetation during April 2005. All tick specimens were frozen at $-60{ }^{\circ} \mathrm{C}$ until examination. Immediately before DNA isolation, ticks were surface sterilized with $70 \%$ ethanol (PCR quality), then pooled (10 ticks per pool) and mechanically disrupted using a sterile glass microblender. The total genomic DNA was extracted with QIAamp DNA Tissue Kit (Qiagen, Hilden, Germany) according to manufacturer's instructions. Molecular detection of B. canis was performed as described previously (Jefferies et al. 2003) including primers PIRO-A1 (5' - AGGGAGCCTGAGAGACGGCTACC - 3') and PIRO-B (5' - TTAAATACGAATGCCCCCAAC - 3') which amplify an approximately 450 bp long conservative region of the $18 \mathrm{~S}$ rRNA gene of babesiae.

\section{Results}

A total of 68 blood samples taken from 41 dogs were examined by PCR. No sample contained DNA of B. canis. Specific antibodies were detected in 5 dogs (12.2\%). Serological examination based on indirect immunofluorescence detected 6 positive serum samples. Titres ranged from 50 to 200. One dog was positive in two samplings within 3 months. The highest number of positive samples was taken in June. The results are demonstrated in Table 1 . A total of 340 adult $D$. reticulatus ticks (210 females and 130 males) in 34 pools were screened for babesiae. Specific PCR products of babesial DNA were not detected in any of the examined pools.

Table 1. Titres of specific antibodies against Babesia canis in positive dogs (IFA)

\begin{tabular}{lccccc}
\hline \multirow{2}{*}{ Breed } & \multirow{2}{*}{ Sex } & \multirow{2}{*}{ Age (years) } & \multicolumn{3}{c}{ Blood examination and titre of specific antibodies } \\
\cline { 3 - 6 } & & 3 & March & April & June \\
\hline Dachshund & Male & 30 & NT & 50 \\
Jagdterrier & Female & 11 & Negative & 100 & NT \\
German & & & & & \\
Shepherd & Male & 5 & Negative & Negative & 50 \\
Dachshund & Male & 8 & Negative & NT & 50 \\
Siberian Husky & Male & 8 & NT & NT & 200 \\
\hline
\end{tabular}

NT- not tested

\section{Discussion}

Canine piroplasms are increasingly more frequently brought to the north (Gothe and Schmid 1995; Losson et al. 1999). The geographical distribution of the causative agent and thus the occurrence of babesiosis are largely dependent on the distribution of the competent vector and susceptible host, therefore being regarded as endemic for certain regions (Martinod et al. 1986). We encounter clinical cases of babesiosis increasingly more often at our clinic. So far, they have been only cases of imported babesiosis, mostly from Slovakia. One of the risk groups is represented by search and rescue dogs that are often used to work abroad. Autochthonous infection has not been observed in the Czech Republic yet.

Examination performed in April 2005 did not detect B. canis in D. reticulatus ticks picked up in the localities where they occur. In 2010, we examined a group of dogs coming 
from the locality with incidence of $D$. reticulatus near the border with Slovakia. Those dogs often worked in the wild, which made them more likely to get into contact with ticks. None of the examined dogs ever left the Czech Republic. Serological examination proved that 5 dogs were positive for antibodies against $B$. canis. In one of these dogs positive titre was observed repeatedly after 3 months (March and June; titer 50 in both cases). In April, one positive result (titre 100) was recorded. The highest number (4) of positive results was observed in June when also the highest titre (200) was recorded. Spring activity of D. reticulatus spans over March throughout April, having the second peak in late summer. Antibodies start to be produced 1 to 2 weeks after contact with the infectious agent. All the examined animals were clinically healthy. Our results indicate a likely contact of the examined dogs with the parasite. If the infectious dose was low, the infection could induce only antibody reaction without the outburst of the disease. In such cases, the parasite's DNA in the samples could be under the detection limit, or the parasite was eliminated.

Babesiae were not detected in the blood of the examined dogs by PCR. This indicates that the parasite was either absent in the samples or there was such a low level of its DNA that it was not possible to detect it by this type of assay. Diagnostics of babesiosis is based on direct detection of the parasite in blood smear or on using PCR method. Serology is used rather for seroepidemiologic studies than clinical diagnostics. Certain studies indicate that up to $36 \%$ of dogs with parasitaemia can be serologically negative (Taboada 1998). In localities with babesiosis, serologically positive dogs should not be used for breeding, even if parasite was not detected in them. In these animals a low level of parasitaemia under the detection limit of microscopy or PCR cannot be ruled out. Subclinical infections of this kind cause problems in breeding kennels and pose a risk in cases of transfusion therapy (Taboada 1998; Birkenheuer et al. 2003; Boozer and Macintire 2003; Irwin 2005).

As far as incidence of babesiosis is concerned, the Czech Republic has a unique position nowadays compared to the adjacent countries where the vector's area is expanding and babesiosis is spreading out. Long-term incidence of Dermacentor reticulatus in the Czech Republic was confirmed only in a relatively small area around the Morava and Dyje rivers in the southeastern part of the country (Fig. 1). Although babesiosis is commonly detected in Slovakia near the Czech national border, no autochthonous clinical case of babesiosis has been confirmed in the Czech Republic yet. The examination of 340 ticks in 2005 did not demonstrate the presence of the parasite's DNA. In 2010, we detected antibodies

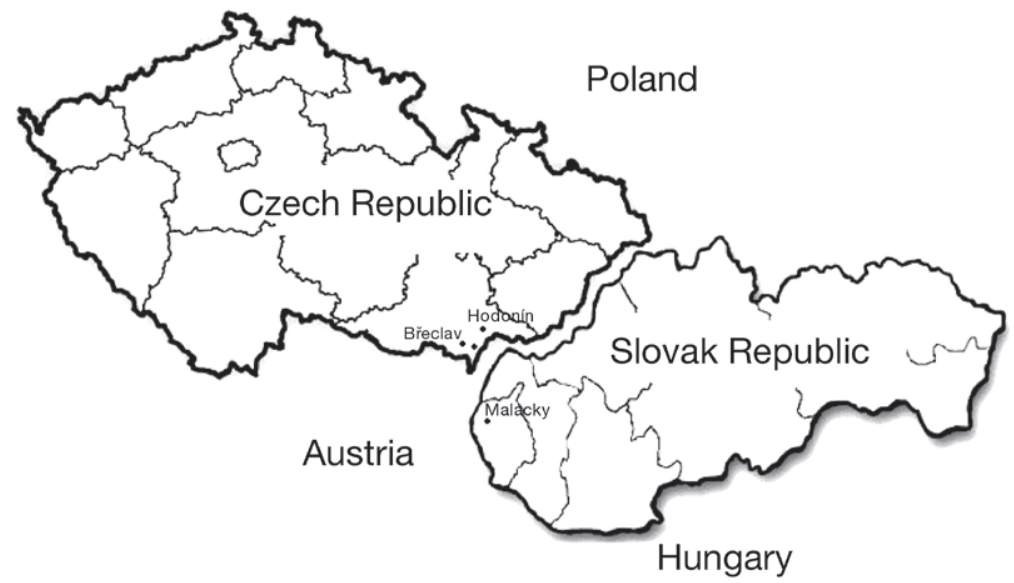

Fig. 1. Localities with the incidence of Dermacentor reticulatus - Hodonín, Břeclav, Lanžhot 
against babesiosis in five dogs $(12.2 \%)$. Although babesiae were not detected directly by PCR, the results of our study indicate that the presence of B. canis in the Czech Republic cannot be excluded. Epidemiological surveillance including distribution of competent vector, detection of the disease agent, seroprevalence study of dogs, and monitoring of acute and imported cases are needed to elucidate whether canine babesiosis could become established in the Czech Republic.

\section{References}

Boozer AL, Macintire DK 2003: Canine babesiosis. Vet Clin Small Anim 33: 885-904

Birkenhauer AJ, Levy MG, Stebbins M, Poore M, Breitschwerdt E 2003: Serosurvey of antiBabesia antibodies in stray dogs and American pit bull terriers and American Staffordshire terriers from North Carolina. J Am Anim Hosp Assoc 39: 551-557

Chandoga P, Goldová M, Baranová D, Kozák M 2002: First cases of canine babesiosis in the Slovak Republic. Vet Rec 150: 82-84

Duh D, Slovák M, Saksida A, Strašek K, Petrovec M, Avšič-Županc T 2006: Molecular detection of Babesia canis in Dermacentor reticulatus ticks collected in Slovakia. Biologia 61: 231-233

Földvári G, Farkas R 2005: Ixodid tick species attaching to dogs in Hungary. Vet Parasitol 129: 125-131

Gothe R, Schmid I 1995: Epidemiological case analysis of dogs with Babesia infection in Germany. Kleintierpraxis 40: $169-179$

Hornok S, Farkas R 2009: Influence of biotope on the distribution and peak activity of questing ixodid ticks in Hungary. Med Vet Entomol 23: 41-46

Hubálek Z, Treml F, Halouzka J, Juřicová Z, Huňady M, Janík V 1996: Frequent isolation of Francisella tularensis from Dermacentor reticulatus ticks in an enzootic focus of tularaemia. Med Vet Entomol 10: 241-246

Irwin P 2005: Babesiosis and cytauxzoonosis. In: Shaw SE, Day MJ (Eds.): Arthropod-borne infectious disease of the dog and cat. Manson Publishing Ltd, London, pp. 120-133

Jefferies R, Ryan UM, Muhlnickel CJ, Irwin P 2003: Two species of canine babesia in Australia: Detection and characterization by PCR. J Parasitol 89: 409-412

Kubelová M, Široký P 2010: Výskyt a šíření psí babeziózy ve střední Evropě (Occurrence and spreading of canine babesiosis in Central Europe). Veterinářství 4: 198-202

Kučera J 1992: Babezióza u psa (Babesiosis in dog). Popis importovaného případu a literární přehled. Veterinářství 42: 371-373

Losson B, Miller JJ, Avez F, Malaise F, Mignon B: 1999. Description of three cases of canine babesiosis in Belgium. Ann Med Vet 143: 119-124

Martinod S, Laurent N, Moreau Y: 1986. Resistance and immunity of dogs against Babesia canis in endemic area. Vet Parasitol 19: 245-254

Sréter T, Széll Z, Varga I 2005: Spatial distribution of Dermacentor reticulatus and Ixodes ricinus in Hungary: evidence for change? Vet Parasitol 128: 347-351

Svobodová Z, Svobodová V 2004: Babesióza psů v České republice. Veterinářství 54: 76-79

Taboada J 1998: Babesiosis. In: Greene CE (Ed.): Infectious diseases of the dog and cat. Saunders Elsevier, Philadelphia, pp. 473-481

Uilenberg G 2006: Babesia - A historical overview. Vet Parasitol 138: 3-10

Vercammen F, De Deken R, Maes L 1997: Duration of protective immunity in experimental canine babesiosis after homologous and heterologous challenge. Vet Parasitol 68: 51-55

Zygner W, Jaros S, Wędrychowicz H 2008: Prevalence of Babesia canis, Borrelia afzelii, and Anaplasma phagocytophilum infection in hard ticks removed from dogs in Warsaw (central Poland). Vet Parasitol 153: $139-142$

Zygner W, Wędrychowicz H 2006: Occurrence of hard ticks in dogs from Warsaw area. Ann Agric Environ Med 13: $355-359$ 